DIGITAL COMMONS
@ UNIVERSITY OF SOUTH FLORIDA

Volume 4

Issue 2 Volume 4.2 (Fall 2014)

\section{ABO: Interactive Journal for Women in the Arts, 1640-1830}

2014

\title{
In Their Hands: Students Editing Eighteenth- and Nineteenth- Century Letters
}

Thomas McLean

University of Otago, thomas.mclean@otago.ac.nz

Follow this and additional works at: https://digitalcommons.usf.edu/abo

Part of the Educational Methods Commons, Feminist, Gender, and Sexuality Studies Commons, and the Literature in English, British Isles Commons

\section{Recommended Citation}

McLean, Thomas (2014) "In Their Hands: Students Editing Eighteenth- and Nineteenth-Century Letters," ABO: Interactive Journal for Women in the Arts, 1640-1830: Vol.4: Iss.2, Article 2.

http://dx.doi.org/10.5038/2157-7129.4.2.2

Available at: https://digitalcommons.usf.edu/abo/vol4/iss2/2

This Pedagogy is brought to you for free and open access by Digital Commons @ University of South Florida. It has been accepted for inclusion in ABO: Interactive Journal for Women in the Arts, 1640-1830 by an authorized administrator of Digital Commons @ University of South Florida. For more information, please contact digitalcommons@usf.edu. 


\title{
In Their Hands: Students Editing Eighteenth- and Nineteenth-Century Letters
}

\begin{abstract}
This article describes an honours-year class conducted in 2013 at the University of Otago in New Zealand. Students transcribed, annotated and wrote essays about a little-known New Zealand collection of unpublished letters written by leading British women writers of the Romantic era. Their research was then collected and published as a book entitled "In Her Hand: Letters of Romantic-Era British Women Writers in New Zealand Collections." The success of this course suggests the benefits of allowing students the opportunity to undertake original archival research and serves as a reminder that rich archival collections are found all over the world.
\end{abstract}

\section{Keywords}

Letters, Correspondence, Archives, British Literature, New Zealand

Creative Commons License

(c) (i) $\odot$

This work is licensed under a Creative Commons Attribution-No Derivative Works 3.0 License. 
Turn your weaknesses into strengths. This has been one of my mantras since I was a teenager, but it has taken on new meaning since I accepted a position in the English Department at the University of Otago in New Zealand. It was at the core of a class I co-taught last year, in which students had to each transcribe, annotate, and write essays about a group of unpublished letters from a Romantic-era woman writer. They also had to share in the work of publishing their findings in a paperback book.

The seeds of this course were planted in October 2004, when I first visited Dunedin for my job interview. I had made substantial use of unpublished manuscripts of British writers in my $\mathrm{PhD}$ dissertation, and I was hesitant to take a job at the research university furthest in the world from the British Library. But I grew up in the American Midwest, and I had learned that unique and fascinating collections show up in unexpected places. So on my first day in Dunedin I visited the university's special collections. I was impressed by the early editions, but the manuscript collection was thin, and the best material had already been published. Otago's special collections librarian, Donald Kerr, suggested I visit the Dunedin Public Library. I thought he was joking, but he wasn't. The library's Heritage Collections held several thousand manuscript letters written by British notables of the eighteenth and nineteenth centuries. I also realized that relatively few scholars knew about this collection.

Well, thought I, even if I don't get the job, I've already made a valuable discovery. In the end I got the job (and grad students, take note: the committee must have been impressed that in fortyeight hours I had learned more about the local collections than almost anyone in the department). And so I went to work.

Over the next few years, I published letters of Joanna Baillie, Jane Porter, and Elizabeth Gaskell from the collection. Indeed, my 2010 edition Further Letters of Joanna Baillie only exists because the Dunedin Public Library got me started with six previously unpublished letters. I also offered my knowledge to librarians who were gradually working through the hundreds of letters not yet catalogued. But I kept hoping that these letters would inspire something larger. I tried to persuade various graduate students of the interesting materials available down the road, but none was particularly interested (oddly enough, few scholars have taken the trouble to contact the library either, despite my repeated suggestions).

A solution came early, though I was slow to see it. During my first two years at Otago, Professor Barbara Brookes in History and Dr. Shef Rogers in English ran an honours-year class called Writing for Publication (New Zealand universities require three years of study for a bachelor's degree; students with a B+ average or higher can apply for a fourth, honours year of advanced coursework, which often leads to MA study). Barbara and Shef limited their class to twelve students. Each student was assigned an episode or figure from the University of Otago's colorful history. Using material from the university archives and the Hocken Library, students wrote research essays on their topics. They critiqued each other's work (and were graded on their care of critique), and they were assigned various production tasks: choosing design elements, obtaining permission for images, organizing a launch. At the end of each class, the whole was published, in-house, as a book and sold to the public.

I was buried in work during those first two years, teaching undergraduates and trying to publish, and I barely noticed what was going on down the hall. It was some years later, perhaps 2010, when the light bulb flickered. Why not run the class with a focus on the library's eighteenth- and 
nineteenth-century manuscript collection? Barbara Brookes was busy with new projects, but my colleague Shef Rogers, an eighteenth-century specialist who edits the journal Script \& Print and the series New Zealand Colonial Texts, was the ideal co-coordinator. We agreed in May 2012 to run the class during the first semester (March-June) of 2013.

We readily adopted the pedagogical goals of the earlier versions of Writing for Publication. The course emphasized the importance of working with primary sources, provided an opportunity for young scholars to undertake original research, and allowed for the development of useful skills that were not often available in English classes: working collaboratively, giving and receiving peer feedback, understanding the essential tasks and considerations of publishing a book, and conscientiously creating a product that would exist in public long after the class was over. Our students would also have to develop a strong knowledge of the life and works of one writer, but we hoped that collaboration, discussion, and peer review would enable each student to become knowledgeable about the lives and works of all eleven writers, and hence the era. Furthermore, we wanted to stress the empowering insight that significant and original research was possible anywhere in the world. We had access to manuscripts that were unknown to scholars in the United Kingdom or North America, and we wanted our students to take advantage of this opportunity.

Our next step was to identify an appropriate group of letters. Most of the letters had been donated to the library in the 1940s by A. H. Reed, a publisher and well-known New Zealand personality. Reed's personal interests included Samuel Johnson and Charles Dickens, but he also purchased miscellaneous bundles of letters from Maggs of London. These included a considerable number of letters from Romantic-era women writers: Lady Morgan, Felicia Hemans, and others. Some, like Hannah More and Anna Barbauld, would have been collected for Reed's grangerized Life of Johnson; others must have been happy accidents. Given my own research interests, it made sense to focus on this part of the collection. With the assistance of rare books librarian Anthony Tedeschi, Shef and I worked our way through the library's manuscript holdings of several dozen possible authors. Some promising folders offered only clipped autographs or brief notes declining dinner dates. But eventually we assembled a list of about fifteen women writers represented by three or more substantial letters. We supplemented our list with letters from three other New Zealand collections and two private collections.

I chose some of the authors because of my familiarity with them: I have written extensively on Jane Porter and Joanna Baillie, so they were obvious choices. Then I looked for authors with strong connections to the authors I knew best. Lady Byron and Anna Jameson were close friends of Baillie; Porter knew Barbauld, Amelia Opie, and Lady Morgan; Lucy Aikin was the niece of Barbauld and neighbor of Baillie. A few were shoo-ins because of the material: the library holds a suitably sentimental letter from Hannah More to the Scottish writer Henry Mackenzie, while one of the letters written by Maria Jane Jewsbury includes a lengthy, unpublished essay reflecting on the pleasures and pains of travel.

Eleven honours students signed up. A few had contacted us ahead of time and requested authors, but most only learned the names of their authors at that first meeting. We discussed each author at some length and practiced transcribing nineteenth-century handwriting. For their first assignment, students had to transcribe their authors' letters and read up about their authors' lives. We were under way. 
Our class met once a week, on Monday afternoons, for three hours. During the first half of the semester, focusing on transcription and annotation, we met at the public library's Heritage Collections; the second half, focusing on editing and book production, took place in a university classroom. After ninety minutes we'd take a coffee break, with someone each week assigned to bake or buy biscuits (that is, cookies). Sometimes these community-building exercises carried over after class to a local pub.

Many Otago honours classes are full year, but Writing for Publication was run as a singlesemester class. As a result, our students really had to hit the ground running. The university has a strong database collection, so the students became adept at using the Dictionary of National Biography, Nineteenth-Century Newspapers Online, and ancestry.com. Alexander Street Press, hearing about our project, generously made some of their databases available to us at no charge.

Each student essay consisted of three elements: an introduction to the author, a discussion of the significance of the new letters, and annotated transcriptions of the letters themselves. The first and third were relatively straightforward; the second took longer. In class we discussed contexts, took turns looking at tricky transcriptions, and identified themes. Some of our letters concerned publishing matters: Anna Jameson pitting the Colnaghi brothers against each other over a contract; Lady Morgan furious over an advertisement for her latest novel. Others concerned personal matters: Jane Porter comforting an old friend at a time of loss; Amelia Opie discussing the impending death of her beloved father. Such topics brought up ethical issues (do we have a right to publish private letters?). Still other letters reminded us of the inaccuracies of any archive. One of our letters from Lady Byron, we discovered, was actually written by the next Lady Byron (though in an exasperatingly similar hand). Each chapter also included two or three illustrations to supplement the text. Some students chose nineteenth-century engravings of the authors or their correspondents, others preferred photographs of the letters themselves. One artistically inclined student included her own portrait of her author. Working together helped the students see the web of friendships and associations that connected so many of our authors. More's letter to Mackenzie found an unexpected echo, thirty years later, in Lady Byron's letter to one of Mackenzie's daughters. In another letter, Lucy Aikin voiced her concern about the well being of her Hampstead neighbors Joanna and Agnes Baillie.

We also took advantage of some twenty-first-century webs of associations. When students reached an impasse in their research—an unidentified Mr. Smith or Mrs. Jones, a smudged sentence or postmark - they would bring their queries to the class or the instructors. Many mysteries were solved this way, but a few inevitably remained. At this point the student and I contacted overseas scholars who were experts on the author in question. In almost every case the scholars were fascinated to learn that such letters survived in New Zealand, and were enthusiastic co-detectives in tracking down missing details. If even these sources reached a dead end, we could relax (at least for the moment) knowing we had thoroughly searched every possibility. Even these dead ends provided a valuable lesson: archival work isn't just about solving a mystery; it's also about limiting possible solutions, so that parts of the puzzle are assembled for some future scholar to add the missing piece. A letter from Lucy Aikin to a Mrs. Gaskell opened the possibility of a previously unknown correspondence between two important writers. But, in the end, we were unable to conclusively identify our Mrs. Gaskell as the Mrs. Gaskell. Instead we provided future scholars with the evidence gathered so far. 
We expected the final essays to come in around three thousand words, but many were closer to five thousand words. In most cases, this was not a problem of overwriting; it was a case of enthusiasm. Our students recognized the rare opportunity given them to be the first to comment on previously unpublished letters written by significant nineteenth-century writers. Inevitably, some students were able to engage in more complex arguments than others. We stressed that it was better to get the basics right than to make unsupportable claims (not every Romantic-era woman writer deserves the title "proto-feminist"). Shef and I edited the essays thoroughly (some students might say ruthlessly), just as we would for a PhD student. But the students also took their peer review work seriously and provided each other with valuable (and sometimes ruthless) advice.

But that was only one half of the project. All along decisions had to be made about the book itself. A visit to the university printery clarified the production process, but many other design dilemmas remained. Identifying our audience was the most pressing issue. We adopted a style that would suit both interested layperson and scholarly expert: students wrote the introductory biographies so that housemates or parents could read them with pleasure, but annotated and discussed the letters so that they might be useful to well-informed scholars. Should we edit the letters for accuracy $\left(\& c, w^{\text {h}}\right)$ or reader's ease (etc., which)? Fired by the insight that (say) "in deed" might have subtle differences from "indeed," and that its use might revivify the word's original meaning, we went for accuracy. Include all postmarks and watermarks, or only those that aided dating? (the latter). What size font? What headings? Should we take on that bane of all authors, the index? (we did). One student produced a cover design to near universal acclaim (there was some dissent about the background color); but coming up with a title (A Miscellaneous Lot?) and a name for our group (Otago English Collective? ENGL404 Collective? or again, A Miscellaneous Lot?) proved more challenging.

As the class proceeded, it became clear that a single semester would not be enough. In the past, the book launch occurred in June; we decided to push it back to mid-July, the start of our second semester. This gave us all a few extra weeks to look over proof pages. Some students and colleagues suggested future versions of the class should take the full year. Perhaps the first month could be focused on further readings about the historical context, or reading important works from the era (some students remarked that they would have enjoyed learning as much about Lord Byron as they did about Lady Byron). We will certainly consider this, but perhaps it's asking too much of a class to both provide a complex overview of a literary era and introduce students to archival and publishing skills. Furthermore, I'd hate to lose the excitement and pressure that produced such good work in the first weeks of our class.

The books reached us from the printery on the morning of the launch. Our initial print run was 125; after these sold out, we printed another 50. The book is sold through our department website, and it has been purchased by research libraries in Australia, New Zealand, and North America. We charge NZ\$22 per copy (about US\$18), which allows us to break even. We might have put our research on the internet and saved ourselves a lot of headaches worrying about printing errors and book sales, but then we would have missed that unforgettable feeling of pride an author feels when she holds her work, well, in her hands, for the first time.

I remember being asked at the launch (and often since) whether such a project is repeatable. New Zealand's manuscript collections are rich enough to support many years of such projects, though the subject would have to change: in future years we might focus on letters of artists, scientists, 
or politicians. The Otago Settlers Museum in Dunedin preserves the travel diaries of numerous nineteenth-century immigrants to New Zealand; perhaps one of these could be a course focus. This is not a class that could be offered annually, however. It was simply too much work. Two or three months after the class had ended, Shef and I were still recovering, and somewhat astonished that we had actually succeeded in reaching our goal.

There was one more lesson to learn (and to continue learning). Most classes end on a specific date, with a recorded mark. But a publication lives on in expected and unexpected ways. As part of the class, we asked a noted scholar of eighteenth- and nineteenth-century women writers, Professor Devoney Looser, to read and respond to the completed book. We required only a short response, but Professor Looser gave thoughtful and detailed comments about each chapter. For many, it was the first time their work had been judged by a stranger, and the first hint of the potential longer life of the book. More recently there have been interviews for radio and newspaper, and a positive review in the quarterly journal New Zealand Books. There have been disappointments as well. Several letters were discovered too late for inclusion-a reminder that complete editions are rarely complete. Less predictably, we discovered that a British literary festival found our book cover on the internet and used (without permission) the image to promote a series of interviews with contemporary women writers! The organizers have since promised to credit our students for their work.

The palpable result of our work is In Her Hand: Letters of Romantic-Era British Women Writers in New Zealand Collections, a 240-page book that includes transcriptions and discussions of almost 60 previously unpublished letters. The less obvious results: eleven students and two instructors with a new awareness of the challenges and pleasures of archival work and book publishing, and the satisfaction of knowing that one doesn't have to be in Boston or Edinburgh to do original work on British literature and culture. We learned to turn weaknesses into strengths. 